\title{
Pelaksanaan Keselamatan Kerja Pada Perusahaan Bongkar Muat
} (PBM)

\author{
Budi Handojo $^{1}$, Pantja Siwi Veny R Ingesti ${ }^{2}$, Sahudiyono ${ }^{3}$, Angga Dwi Setiawan ${ }^{4}$ \\ ${ }^{1,3}$ Prodi Managemen Transportasi Laut, Sekolah Tinggi Maritim Yogyakarta, Jl. \\ Magelang Km 4,5 Yogyakarta 55284, Indonesia \\ ${ }^{2}$ Politeknik LPP, Jl. Urip Sumoharjo No.1, Klitren, Kec. Gondokusuman, Kota \\ Yogyakarta, Daerah Istimewa Yogyakarta 55222 \\ ${ }^{4}$ Taruna Prodi Managemen Transportasi Laut, Sekolah Tinggi Maritim Yogyakarta, Jl. \\ Magelang Km 4,5 Yogyakarta 55284, Indonesia \\ *Coresponding Author : E-mail : budihandojo1961@gmail.com.Hp. 082133751697
}

\begin{abstract}
Abstrak
Tujuan penelitian ini adalah sebagai upaya menjelaskan standar keselamatan kerja dan prosedur yang berlaku dalam bongkar muat barang di perusahaan bongkar muat serta sebagai upaya perusahaan bongkar muat dalam menanggulangi resiko-resiko pelaksanaan pekerjaan dan kecelakaan kerja. Metode penelitian menggunakan pendekatan diskriptif kualitatif. Pelaksanaan penelitian di PT. Berkah Tata Baruna Di Pelabuhan Merak Banten. Hasil penelitian yang dapat disampaikan bahwa untuk memberikan perlindungan dan keamanan maka perusahaan bongkar muat telah memberikan standar keselamatan kerja bongkar muat serta diberikan prosedur (SOP) pada setiap operasional bongkar muat barang. Demikian juga PBM telah memberikan pentingnya pencegahan dan penanggulangan, risiko-risiko keselamatan kerja melalui penerangan, pelatihan SDM, penggunaan alat keselamatan, serta usaha - usaha unit tanggap darurat atas terjadinya kecelakaan kerja. Kesemuanya telah sesuai menurut Peraturan perundang-undangan yang berlaku, seperti UU Nomor 1 Tahun 1970, UU Nomor 13 Tahun 2003, UU Nomor 152 Tahun 2016.
\end{abstract}

Kata Kunci : Perlindungan, Keselamatan Kerja dan Bongkar Muat

\begin{abstract}
The purpose of this study is as an effort to explain work safety standards and procedures that apply in loading and unloading goods during loading and unloading and as an effort by loading and unloading companies in tackling the risks of carrying out work and work accidents. The research method uses a qualitative descriptive approach. Implementation of research at PT. Blessings of Tata Baruna At the Banten Merak Harbor. The results of the research that can be conveyed are that in order to provide protection and security, the unloading company has provided unloading work safety standards and procedures (SOP) provided for each loading and unloading operation. Likewise, PBM has provided important prevention and countermeasures, occupational safety risks through lighting, HR training, use of safety equipment, as well as emergency response efforts for work accidents. All of them are in accordance with applicable laws and regulations, such as Law Number 1 of 1970, Law Number 13 of 2003, Law Number 152 of 2016.
\end{abstract}


Keywords : Protection, Occupational Safety, Loading Unloading

\section{PENDAHULUAN}

Dalam kegiatan yang dilakukan oleh Perusahaan Bongkar Muat (PBM) memindahkan muatan dari dermaga ke kapal atau sebaliknya yaitu Stavedoring. Stavedoring adalah jasa bongkar/muat dari/ke kapal, dari/ke dermaga, tongkang, gudang, truk atau lapangan dengan menggunakan derek kapal atau alat bantu pemuatan lainnya. Orang yang bertugas mengurus bongkar muat disebut sebagai stavedore. Stavedore yang bertugas di atas kapal disebut stavedore kapal, sedangkan stavedore yang bertugas di darat disebut sebagai quay supervisor. Dalam bekerja, stavedore dibantu fareman yang mesti koordinasi kegiatan bersama Stavedoring di atas kapal dengan di darat dilakukan oleh seorang chief stavedore atau terminal operator(Suyono, 2003). Bongkar dan memuat isi muatan kapal yang mana setiap kapal memiliki jenis muatan barang tersendiri seperti general cargo. Banyaknya barang yang akan dibongkar muat dalam kapal membutuhkan tenaga kerja yang cukup banyak untuk membongkar isi muatan kapal ke gudang penyimpanan sementara kegiatan bongkar muat tersebut di dalamnya terdapat aktivitas seperti stevedoring, cargodooring, dan receiving(Iswanto, 2016).

Kasus-kasus kecelakaan kerja yang berada di lapangan termasuk pelabuhan yaitu kurangnya perawatan sling pada crane membuat sling kusut atau tidak lancar saat pemakaian yang mengakibatkan terjadinya gesekan pada dinding palka kapal. Kesalahan prosedural stuffing/unstuffing yang mengakibatkan ketidakseimbangan posisi peti kemas yang berada di atas chassis dan yang selanjutnya tidak kepedulian terhadap SWL yang mengakibatkan patahnya telescopic boom. Sedang menurut (Suma'mur, 1981) bahwa pentingnya keselamatan kerja dan perlindungan tenaga kerja agar tenaga kerja secara aman melakukan pekerjaannya sehari-hari untuk meningkatkan produksi dan produktivitas. Tenaga kerja harus memperoleh perlindungan dari pelbagai soal sekitarnya dan pada dirinya yang dapat menimpa dan mengganggu dirinya serta pelaksanaan pekerjaannya.

Selanjutnya untuk itu perusahaan bongkar muat terikat untuk mentaati ketentuan Undang Undang No. 1 Tahun 1970, Tentang Keselamatan Kerja, 1970 Pasal 9 ayat (3) ; Pengurus diwajibkan menyelenggarakan pembinaan bagi semua tenaga kerja yang berada dibawah pimpinannya, dalam pencegahan kecelakaan dan pemberantasan kebakaran serta meningkatkan keselamatan dan kesehatan kerja , pula dalam pemberian pertolongan pertama pada kecelakaan. Dalam bekerja keselamatan merupakan faktor yang sangat penting untuk diperhatikan karena seseorang yang mengalami sakit atau kecelakaan dalam bekerja akan berdampak pada diri, keluarga, dan lingkungannya. Faktor penyebab kecelakaan karena adanya keterbatasan fasilitas keselamatan kerja dan pemahaman faktor-faktor prinsip yang perlu diterapkan perusahaan. Makna keselamatan dan kesehatan kerja (K3) adalah memandang setiap karyawan di perusahaan memiliki hak atas perlindungan kehidupan kerja yang nyaman dan ketenangan dalam melaksanakan pekerjaan(Supartini et al., 2021). Contoh kecelakaan saat bekerja seperti seorang tally man yang meninggal akibat terkena sabetan tali wayer trolly yang putus, 
pekerja kasar bongkar muat yang patah karena tertimpa barang berat ,dan selanjutnya seseorang yang tewas karena tertimpa crane. Agar tidak terjadi lagi maka pelaksanaan K3 segera dilakukan untuk menciptakan tempat kerja yang aman, sehat, bebas dari pencemaran lingkungan, sehingga dapat mengurangi kecelakaan kerja dan penyakit akibat kerja yang pada akhirnya meningkatkan efisiensi dan produktifitas kerja (Tarwaka, 2008).

PM Perhubungan RI Nomor 152 Tahun 2016: Tentang Perusahaan Dan Pengusahaan Bongkar Muat Dari Dan Ke Kapal, Pasal 19 Permenhub tersebut menyebutkan bahwa , Untuk mengurangi resiko tanggung jawab serta menjamin pihak-pihak yang dirugikan, pelaksana kegiatan bongkar muat wajib mengasuransikan tanggung jawabnya. Dalam melakukan pelayanan, perusahaan bongkar muat harus bekerja sama dengan berbagai pihak seperti perusahaan pelayaran, EMKL, pemilik barang, penyedia tenaga buruh dan sebagainya. Masingmasing pihak memiliki tugas dan tanggung jawab. Sedangkan tanggung jawab dari perusahaan bongkar muat adalah kelancaran kegiatan bongkar muat, keselamatan penerimaan dan penyerahaan barang, kebenaran laporan yang disampaikan, mengatur penggunaan tenaga kerja bongkar muat dan peralatan sesuai kebutuhan. (Soekanto, 2007). Di dalam menajemen resiko dikatakan (Darmawi, 2014) bahwa pegawai dan direktur dunia usaha mempunyai tanggung jawab hukum terhadap pemegang saham atau pemilik perusahaan bagi pengelolaan resiko murni. Beberapa keputusan pengadilan menekankan bahwa direktur dan karyawan mungkin memikul tanggung jawab resmi bila terjadi pelanggaran dan kewajiban tersebut.

Dalam mengerjakan bongkar/muat dari dan ke kapal, selain foreman juga ada beberapa petugas lain yang membantu stvedore, yaitu: (a) Cargo surveyor perusahaan PBM, yaitu petugas survei yang mencatat dan memeriksa keadaan fisik barang yang dimuat/bongkar dari dan ke kapal dalam hubungannya dengan klaim, termasuk chief tally clerk, tally clerk, dan watchman. (b) Petugas barang berbahaya yang khusus mengawasi barang berbahaya yang akan dimuat/bongkar dari kapal atau sebaliknya dari darat. (c) Kasap, yaitu petugas peralatan yang siap di terminal peralatan untuk melayani kapal yang bongkar/muat.dan (d) Administrasi, yaitu petugas-petugas yang mempersiapkan administrasi, yaitu hatch-list, stwage plan, statement of facts, labour and time sheets, daily report, tally sheet, dan lain-lain (Suyono, 2003).

Seorang tokoh dan pejuang keselamatan kerja (Suma'mur, 1981) menyatakan bahwa difinisi keselamatan kerja adalah keselamatan yang bertalian dengan mesin, pesawat, alat kerja, bahan dan proses pengolahannya, landasan tempat kerja dan lingkungannya serta cara-cara melakukan pekerjaan. Keselamatan kerja bersasaran segala tempat kerja, baik di darat, di dalam tanah, di permukaan air, di dalam air maupun di udara. Tempat-tempat kerja demikian tersebar pada segenap kegiatan ekonomi, seperti pertanian, industri , pertambangan, perhubungan, pekerjaan umum, jasa , dan lain-lain. Serta menyangkut segenap proses produksi dan distribusi, baik jasa maupun barang. Untuk menerapkan keselamatan kerja pada perusahaan maka terdapat prinsip-prinsip yang biasanya dapat diikuti oleh seorang pemimpin perusahaan dalam perencanaan keselamatan dan efisiensi produksi. Di bawah ini adalah misal-misal sebagai berikut : (a) Usahakan pengelolaan material dan bahan dengan kontak sedikit mungkin, (b) Ciptakan keadaan-keadaan yang 
aman untuk berjalan di lantai, tangga-tangga, lorong-lorong, dataran kerja, dan sebagainya, (c) Sediakan luas yang cukup bagi mesin dan peralatannya, (d) Upayakan pencapaian seaman mungkin ke setiap tempat yang menjadi tujuan tenaga kerja, (e) Adakan keselamatan bagi pekerja-pekerja yang melakukan perawatan dan perbaikan alat, (f) Sediakan jalan penyelamatan yang tepat manakala terjadi kebakaran, dan (g) Sediakan ruang untuk pengembangan. (Keselamatan kerja dan pencegahan kecelakaan.

Berdasarkan Undang Undang No. 1 Tahun 1970, Tentang Keselamatan Kerja, 1970, Pasal 3 ayat (1( menyebutkan bahwa dengan peraturan perundang-undangan ditetapkan syarat-syarat keselamatan kerja untuk ; (a) mencegah dan mengurangi kecelakaan, (b) mencegah dan mengurangi dan memadamkan kebakaran (c) mencegah dan mengurangi bahaya peledakan, (d) memberi kesempatan atau jalan menyelamatkan diri pada waktu kebakaran atau kejadian-kejadian yang berbahaya, (e) Memberi pertolongan pada kecelakaan, (f) memberi alat-alat perlindungan diri pada para pekerja, (g) Mencegah dan mengendalikan timbul atau menyebar luasnya suhu, kelembaban ,debu, kotoran, asap, uap, gas, hembusan angin, cuaca, sinar atau radiasi, suara dan getaran, (h) mencegah dan mengendalikan timbulnya penyakit akibat kerja baik phisik maupu psychis, peracunan, infeksi dan penularan (i) memperoleh penerangan yang cukup dan sesuai, (j) menyelenggarakan suhu dan lembab udara yang baik, (k) menyelenggarakan penyegaran udara yang cukup, (l) memelihara kebersihan , kesehatan dan ketertiban, (m) memperoleh keserasian antara tenaga kerja , alat kerja, lingkungan, cara dan proses kerjanya, (n) mengamankan dan memperlancar pengangkutan orang, binatang, tanaman dan barang, (o) mengamankan dan memelihara segala jenis bangunan, (p) mengamankan dan memperlancar pekerjaan bongkar muat,perlakuan dan penyimpanan barang, (q) mencegah terkena aliran listrik yang berbahaya, dan (r) menyesuaikan dan menyempurnakan pengamanan pada pekerjaan yang bahaya kecelakaannya menjadi bertambah tinggi.

Kecelakaan-kecelakaan akibat kerja yang sering terjadi banyak disebabkan oleh faktor manusia dan sedikit yang dipengaruhi oleh faktor alat. Adapun faktor manusia banyak dipengaruhi oleh : (a) Latar Belakang Pendidikan yaitu bahwa pendidikan banyak mempengaruhi tindakan seseorang dalam bekerja. Orang yang memiliki pendidikan yang lebih tinggi cenderung berpikir lebih panjang atau dalam memandang sesuatu pekerjaan akan melihat dari berbagai segi. (b) Psikologis, yaitu faktor psikologis juga sangat mempengaruhi terjadinya kecelakaan kerja. Psikologis seseorang sangat berpengaruh pada konsentrasi dalam melakukan suatu pekerjaan. Bila konsentrasi sudah terganggu maka akan mempengaruhi tindakantindakan yang akan dilakukan ketika bekerja. Sehingga kecelakaan kerja sangat mungkin terjadi. (c) Faktor Keterampilan, yaitu faktor keterampilan di sini bisa diartikan pengalaman seseorang dalam melakukan suatu pekerjaan. (d) Faktor Fisik yaitu lemahnya kondisi phisik seseorang berpengaruh pada menurunnya tingkat konsentrasi dan motivasi dalam bekerja. Sedangkan kita tahu bahwa konsentrasi dan motivasi sangat dibutuhkan ketika bekerja. Bila sudah terganggu, kecelakaan sangat mungkin terjadi.

Dari uraian latar belakang di atas dapat dirumuskan permasalahan yaitu bagaimana penerapan ketentuan peraturan perundang-undangan dalam pelaksanaan 
keselamatan kerja bongkar muat, agar kegiatan dapat berjalan sebagaimana mestinya. Di dalamnya mencakup aspek-aspek standar keselamatan kerja, prosedur pelaksanaan bongkar muat barang dan upaya mencegah terjadinya kecelakaan kerja. Sehingga PBM dapat melaksanakan kegiatan bongkar muat barang general cargo di Pelabuhan Merak, Banten secara aman, lancar dan selamat. Penelitian ini bertujuan untuk mengetahui pelaksanaan keselamatan kerja bongkar muat pada PT. Berkah Tata Baruna di Pelabuhan Merak Banten. Standar keselamatan kerja yang berlaku, prosedur pelaksanaan bongkar muat dan pencegahan resiko keselamatan kerja bongkar muat. Sehingga dapat diketahui kendala yang terjadi pada penerapan ketentuan perundang-undangan tentang keselamatan kerja serta sebagai upaya perusahaan bongkar muat dalam menanggulangi resiko-resiko pelaksanaan pekerjaan dan kecelakaan kerja di perusahaan bongkar muat.

\section{METODE PENELITIAN}

\section{Metode Pengumpulan Data}

Penelitian ini menggunakan metode pengumpulan data sebagai berikut ; (1) Metode Interview (wawancara) yaitu tidak lain adalah pemaparan atau menguraikan yang menggambarkan permasalahan proses tanya jawab dalam penelitian yang berlangsung secara lisan dalam mana dua orang atau lebih bertatap muka mendengar secara langsung informasi-informasi atau keteranganketerangan.(2) Metode Observasi (pengamatan) yaitu alat pengumpulan data yang dilakukan dengan cara mengamati dan mencatat secara sistematik gejala-gejala yang diselidiki. (Narbuko \& Achmadi, n.d.) dan (3) Metode Dokumentasi yaitu penumpulan data yang sudah dihimpun oleh pihak lain ataupun yang ada pada perusahaan atau instansi terkait, media massa yang ada hubungannya dengan masalah pokok judul. (Hadi, 1978). Sehingga penulis sangat banyak terbantu oleh karena data dokumentasi Peraturan perundang-undangan bidang keselamatan kerja dan kegiatan bongkar muat barang dari dan ke kapal yang penulis peroleh dari perpustakaan Stimaryo Yogyakarta dan mengunduh internet, berwujud sumber hukum primer dan sekunder (Marzuki, 2007).

\section{Metode Analisa data}

Penyajian penelitian ini adalah secara diskriptif-kualitatif dan pemecahan masalahnya. Menurut Agusta dalam Wibowo (2021) metode pendekatan deskriptif-kualitatif adalah metode pengolahan data dengan cara menganalisa faktor-faktor yang berkaitan dengan objek penelitian dengan penyajian data secara lebih mendalam terhadap objek penelitian. Menurut Sugiyono dalam Audi et al.(2021) dalam penelitian diskriptif-kualitatif peneliti adalah sebagai instrumen kunci. Pendekatan kualitatif sebenarnya merupakan tata cara penelitian yang menghasilkan penyajian data secara diskriptik (Soekanto, 2007). Berdasarkan pendekatan tersebut dalam penelitian ini menggunakan metode analisa kualitatif, yaitu semua data yang diperoleh dari hasil penelitian akan disistematisasi berdasarkan kualitas kebenaran sesuai dengan materi penelitian untuk kemudian dikaji secara logis dan relevan. 


\section{HASIL PENELITIAN}

\section{Standar Pelaksanaan Keselamatan Kerja Pbm}

Sebagaimana menurut rumusan masalah, bagaimana pelaksanaan keselamatan bongkar muat general cargo ke dermaga pada PBM PT. Berkah Tata Baruna serta saat bongkar muat berlangsung di Pelabuhan Merak Banten. Sebagaimana diutarakan oleh (Barasa Larsen and Sumali Bambang, 2019) bahwa kegiatan bongkar muat merupakan bagian dari Material Handling, yaitu memuat dan membongkar, yang dilakukan secara berulang-ulang in-efisiensi kecil yang terjadi satu kali handling dapat bertumpuk sehingga menjadi kerugian besar dalam jangka waktu tertentu.

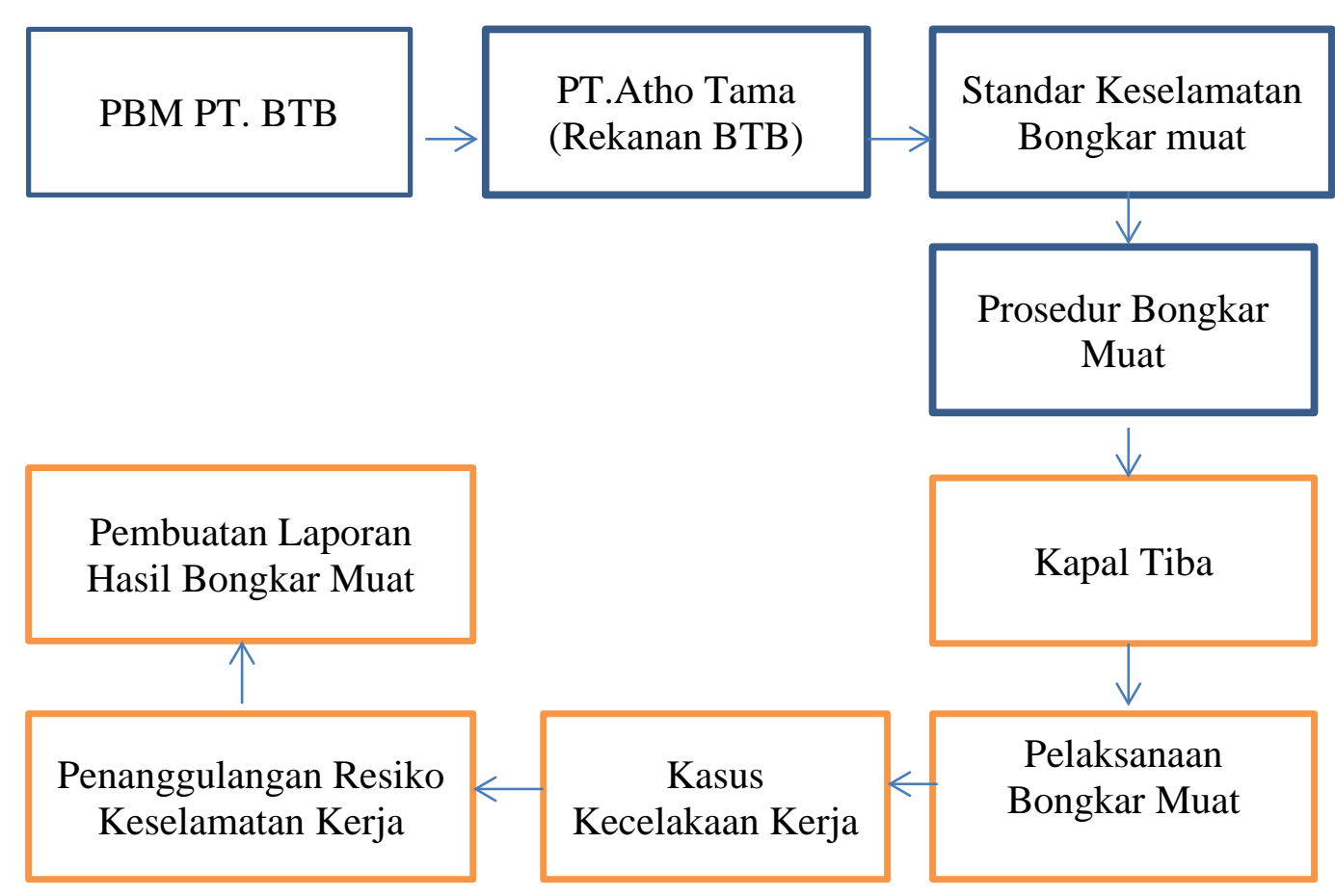

Gambar 1 : Skema keselamatan kerja serta proses pembongkaran muatan

Standar Keselamatan kerja cukup penting bagi para pekerja dikarenakan untuk melindungi keselamataan saat melakukan sesuatu yang berhubungan dengan fisik. Untuk itu ada beberapa faktor yang harus diutamakan :

\section{Alat Pelindung Diri (APD)}

Alat pelindung diri yang dikenakan tenaga kerja secara individual untuk melindunginya dari bahaya atau kondisi seperti penyinaran, kebisingan, kekurangan oksigen, dan benturan/kejatuhan benda-benda keras. APD (personal protective equipment) mampu melindungi TKBM dengan mengurangi kemungkinan serta akibat resiko di tempat kerja, baik terhadap kecelakaan kerja maupun terhadap penyakit akibat kerja. Alat pelindung diri yang harus digunakan 
bagi tenaga kerja ketika berada dan beraktivitas di tempat kerja pada umumnya meliputi :

(a) Pelindung Kepala, yaitu APD pelindung kepala mempunyai 3 spesifikasi seperti 1) Topi pengaman (safety helmet) untuk melindungi kepala dari benturan atau pukulan benda keras, 2) Topi tudung untuk melindungi kepala dari api, uap korosif, debu, dan iklim yang buruk, dan 3). Tutup kepala untuk menjaga kebersihan kepala dan rambut, dan mencegah rambut terlilit bagian berputar.

(b) Pelindung Telinga, yaitu APD perlindungan telinga sebagai penutup telinga dari frekuensi yang melampaui ambang batas normal, terdiri dari : 1) Sumbat telinga (ear plug), dan 2) Tutup telinga (ear muff)

(c) Pelindung muka dan mata, yaitu APD pelindung muka dan mata (face shield) terbuat dari bahan kaca atau plastik, berfungsi melindungi muka dan mata terhadap : 1) Loncatan benda panas, 2) Loncatan potongan benda mekanis, 3) Pengaruh cahaya (optis), dan 3) Pengaruh radiasi

(d) Pelindung pernapasan, yaitu APD pelindung pernapasan berfungsi untuk melindungi sistem pernapasan terhadap sumber atau zat kontaminan dalam udara di tempat kerja, di antaranya :1) Kekurangan oksigen, dan 2) Pencemaran partikel debu, kabut, asap, uap, dan gas. Pelindung Pernapasan yaitu terdiri dari jenis : 1) Respirator yang berfungsi memurnikan udara, 2) Respirator yang terhubung dengan supply udara bersih, dan 3) Respirator dengan persediaan oksigen

(e) Pakaian kerja, yaitu APD berupa pakaian kerja berfungsi melindungi tenaga kerja terhadap radiasi dari suatu objek panas seperti di kamar ketel uap, dan terhadap zat kontaminan di tempat kerja.

(f) Sarung tangan, yaitu APD berupa sarung tangan berfungsi melindungi tangan dan jari-jari terhadap benturan/pukulan, luka, lecet, infeksi, api, radiasi, elektro magnetik, arus listrik, dan bahaya kimia beracun.

(g) Pelidung kaki, yaitu APD pelindung kaki berfungsi melindungi kaki dari :1) Tersandung atau tergelincir, 2) Infeksi terkena bahan kimia, 3) Tertimpa benda berat, dan 4) Terbakar kena tetesan logam cair atau bahan kimia korosif. Tenaga kerja industri berat dilindungi dengan sepatu keselamatan (safety shoes) atau sepatu boot terbuat dari bahan kulit, karet, atau plastik dan bagian yang menutup jari kaki diberi lapisan logam atau campuran baja, pakai sol anti slip, sol jahit atau direkat tanpa paku.

\section{Pelaksanaan K3 pada saat Bongkar Muat General cargo}

Potensi bahaya dan resiko fatal saat di pelabuhan atau terminal yaitu menangani muatan. Sehingga kita perlu menggunakan alat yang sesuai dengan prosedur kerja aman untuk meminimumkan kemungkinan seseorang mengalami cidera karena terhantam oleh muatan yang sedang berayun, diangkat, atau terjatuh selama kegiatan bongkar muat. Hanya petugas yang ditunjuk/ memiliki ijin diperkenankan mengoperasikan peralatan, dengan ketentuan : (a) Pastikan jalur spreader aman dari kendaraan bergerak, (b) Tangani general cargo sesuai dengan muatan kerja aman (safe working load / SWL ) alat, (c) Lakukan pemeriksaan sebelum mengoperasikan alat, (d) Penanganan muatan mutlak dilakukan oleh petugas yang terlatih, (e) Dilarang berada di bawah muatan yang menggantung, (f) Pastikan alat angkat dipelihara dan dirawat secara berkala dan bersertifikat dan (g).

Majalah Ilmiah Bahari Jogja | 32 | http://jurnal.stimaryo.ac.id/index.php/MIBJ/ 
Diberikannya balok kayu di samping lambung kapal untuk menurunkan muatan agar tidak terjadi peyok saat di turunkan dari kapal.

\section{Alat Pemadam Api Ringan}

APAR tersedia dalam berbagai jenis dan ukuran. Penggunaanya disesuaikan menurut pembagian kelas yang ditentukan berdasarkan bahan (material) yang menyebabkan terjadinya kebakaran (Santosa et al., 2021). Kebakaran mulai berlangsung ketika tiga unsur tergabung menjadi satu yakni bahan mudah terbakar, sumber api, dan zat pembakaran atau ' A fire startswhen the following three factors come together : (!) Combustible material - flue (2) Ignition source - heat, (3) Oxygen’’.

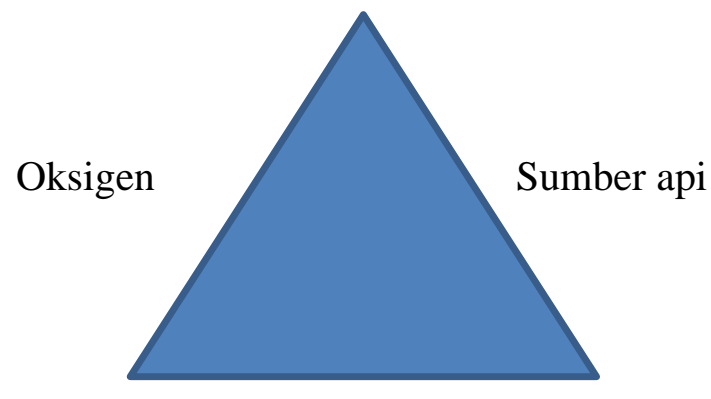

Material

Gambar 2: Segitiga Api

Memandamkan api dalam peristiwa kebakaran dengan menghilangkan satu unsur atau lebih dari tiga unsur (By removing one or more of these factors the fir will be subdued) sebagaimana ditunjukkan dengan segitiga api dalam gambar tersebut di atas. Klasifikasi kebakaran terbagi menjadi empat yakni :1) Kelas A terdiri dari material padat non-logam seperti kain, kayu, karet, kertas, plastik, 2) Kelas B terdiri material cair dan gas seperti bahan bakar minyak, pelumas, gemuk, LPG.3) Kelas C terdiri dari alat-alat dan instalasi bertegangan listrik, dan 4). Kelas D terdiri dari bahan logam seperti magnesium, sodium, titanium, zirconium, pottasium.

\section{Instalasi Pemadam Kebakaran}

Kemampuan pemadaman kebakaran APAR hanya terbatas pada titik-titik api yang relatif tergolong kecil atau masih pada tahap awal. Sedangkan untuk api yang sudah bertumbuh menjadi besar seperti kebakaran gedung bertingkat, kapal, atau instalasi suatu industri, alat pemadaman yang digunakan tidak cukup APAR melainkan ditambah instalasi terpasang secara permanen. Pemanfaatan air sebagai media pemadam dipraktikan secara luas karena air dalam jumlah besar mudah didapat dan efektif untuk bahan padat. Walaupun demikian air memiliki keterbatasan dan sifat tertentu sehingga tidak digunakan terhadap kebakaran minyak dan peralatan atau instalasi bertegangan listrik(Wibowo et al., 2021). 


\section{Prosedur Bongkar Muat Barang}

PBM PT. Berkah Tata Baruna sebelum melaksanakan kegiatan bongkar muat, perusahaan pelayaran memberikan Surat Perintah Kerja (SPK) terhadap Perusahaan Bongkar Muat rekanan. Adapun persiapan-persiapan yang harus dilakukan oleh PBM , sebagaimana pelayanan pelabuhan yang menyangkut Jasa dermaga, yaitu setiap barang yang dimuat dan dibongkar lewat dermaga dan untuk barang-barang yang ditumpuk sementara, baik digudang maupun di lapangan terbuka (Agung, 2019). Sehingga yang diperlukan dan apa saja yang dilakukan demi kelancaran kegiatan bongkar muat general cargo,dapat berjalan lancar . Adapun persiapannya sebagai berikut :

\section{Prosedur Sebelum Kapal Datang}

Sebelum pelaksanaan kegiatan bongkar muat di Pelabuhan Merak Banten harus disiapkan sesuai dengan peraturan-peraturan atau ketentuan internasional maupun nasional yang berlaku sebagai berikut :

Rapat/Floating, Sebelum semua kegiatan dilaksanakan semua pihak yang bersangkutan melakukan rapat di kantor PBM PT. Berkah Tata Baruna untuk melakukan rapat/floating untuk membahas perihal sebagai berikut :1) Untuk mengetahui jadwal kapal tiba di Pelabuhan Merak Banten,2) Untuk mengetahui jadwal kapal akan sandar di Pelabuhan Merak Banten.3) Menentukan kapal sandar di dermaga yang kosong sesuai dengan jadwal pembongkaran tersebut.4) Menentukan jadwal kapal bongkar dari jam yang sudah ditentukan sampai jam yang sudah ditentukan, dan 5). Biasanya rapat dilakukan 2 (dua) kali sebelum kapal sandar di dermaga untuk memastikan ada tidaknya perubahan dari hasil yang ditentukan di rapat pertama atau tidak.

\section{Persiapan Dermaga}

Persiapan yang paling utama adalah dermaga karena sebagai ruang atau tempat untuk kapal bersandar dan melakukan kegiatan bongkar muat. Faktor kesiapan dermaga disini juga dapat menganggu kelancaran kegiatan bongkar muat. Hal ini terjadi karena keterlambatan kapal lain yang melakukan bongkar muat sehingga kapal berikutnya yang akan melakukan sandar dan melakukan kegiatan bongkar muat harus tertunda dan menunggu sampai kegiatan tersebut selesai.

Untuk memakai dermaga ini PT. Berkah Tata Baruna harus mengajukan permohonan pemakaian dermaga kepada general manager PT. Pelindo untuk meminta persetujuan pemakaian pemakaian dermaga sebagai tempat kegiatan bongkar muat barang dari dan ke kapal.

\section{Prosedur dan Tahapan Bongkar Muat}

Pihak PBM diwakilkan oleh Kepala operasional membuat intruksi kerja untuk memberi tahu kepada bagian logistik, foreman, trucking, chief checker, lapangan, heavy lift. Berikut ini merupakan gambaran prosedur bongkar muat yang dilakukan oleh PBM PT.Berkah Tata Baruna. 


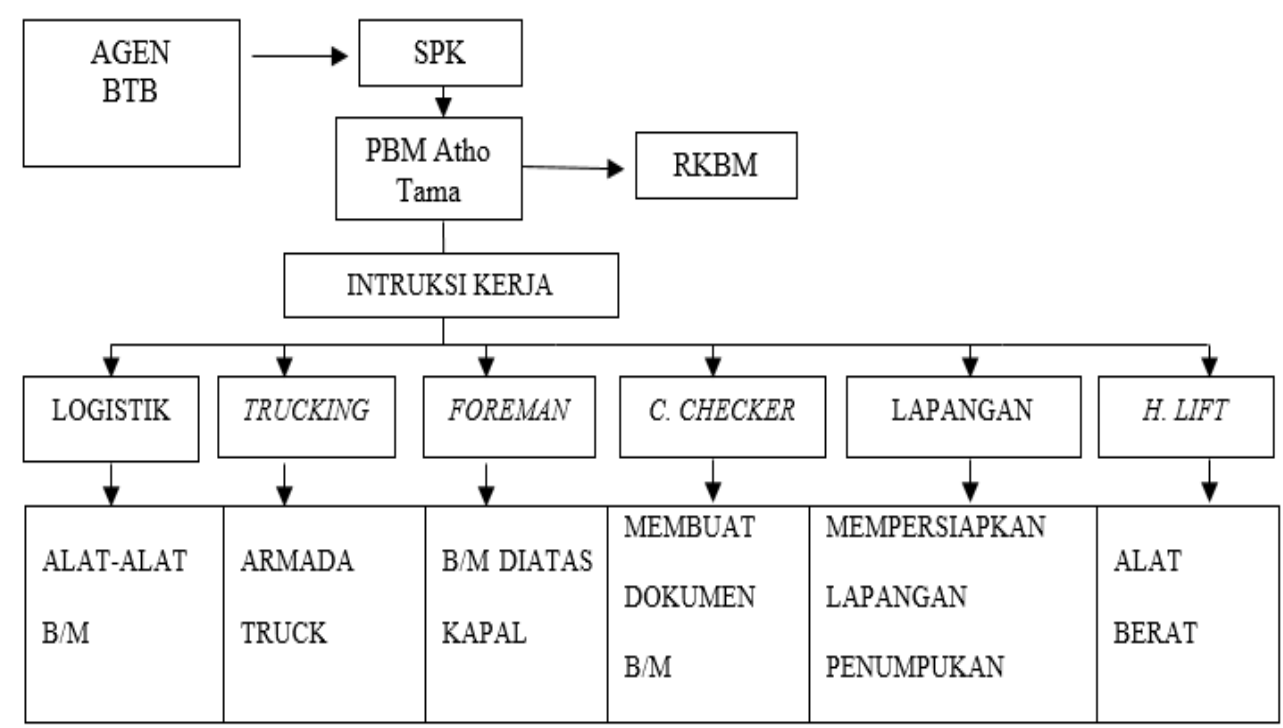

Gambar 3 : Prosedur dan Tahapan Bongkar Muat

\section{Persiapan Alat Bongkar Muat}

Peralatan yang harus dipersiapkan untuk kegiatan bongkar muat barang general cargo ada dua jenis yaitu alat mekanis dan alat non mekanis, sebagaimana dibutuhkan untuk mengangkat dengan menyesuaikan jenis barang tersebut. Peralatan-peralatan bongkar muat mekanis dan non mekanis sebagai berikut : (a) Peralatan Bongkar Muat Mekanis, yaitu Alat-alat mekanis yang digunakan untuk kegiatan bongkar muat general cargo harus memenuhi syarat dan harus lengkap, antara lain sebagai berikut, (b) Crane Kapal, yaitu Alat yang digunakan untuk mengangkat barang baik ke dalam palka ataupun dari palka, dan biasanya alat ini ditempatkan secara permanen di atas kapal. Penggunaanya juga tergantung dengan kesepakatan saat persiapan sebelum melakukan kegiatan bongkar muat. Apakah akan menggunakan crane kapal atau menggunakan crane darat. (c) Forklif Alat bantu berupa kendaraan yang digunakan untuk memindahkan barang dengan kapasitas tertentu dan mempunyai jangkauan yang terbatas dari satu tempat ke tempat yang lain. Biasanya digunakan untuk memindahkan barang atau mengeluarkan barang baik dari dalam gudang maupun sebaliknya. 3) Head Truck, yaitu Alat yang digunakan untuk mengangkat barang-barang yang berupa general cargo untuk diangkut ke lapangan penumpukan yang dibongkar dari kapal

Selanjutnya harus tersedia peralatan bongkar muat non mekanis, yaitu alat yang perlu dipersiapkan dan seringkali digunakan antara lain; (a) Sling, yaitu Alat bongkar muat non mekanis berupa tali yang digunakan untuk mengangkat barang dengan dipasang di tackle crane. Sling yang selalu digunakan oleh PBM ada dua jenis yaitu wire sling dan webb sling. (b) Wire sling, yaitu Sling yang terbuat dari baja digunakan untuk mengangkat barang-barang yang besar dan berat seperti halnya mengangkat pipa pada saat pembongkaran muatan, (c) Webb Sling, yaitu Alat untuk mengangkat barang khusus untuk muatan yang dikemas dalam bentuk 
general cargo seperti yang dimuat/ dibongkar di kapal tanpa dikemas seperti ban, pipa, besi dan lain-lain,(d) Hook, yaitu Alat bongkar muat non mekanis yang digunakan untuk mengangkat barang yang dipasang diujung sling untuk kemudian dikaitkan langsung dengan barang yang akan diangkat. Untuk muatan yang berupa drum menggunakan hook khusus yaitu drum hook. dan pipa., dan (e) Shackle, yaitu Alat penghubung antara sling dengan masterlink atau cincin dan penghubung antara sling dengan hook.

\section{Persiapan Personil (SDM)}

Dalam melakukan proses bongkar muat general cargo diperlukan adanya kerja sama dan koordinasi antara personil di lapangan agar proses bongkar muat dapat berjalan dengan lancar, efisien dan efektif. Oleh karena itu bagian operasional harus mempersiapkan personel yang akan melaksanakan proses bongkar muat seperti : (a) Foreman, yaitu pelaksana dan pengendali bongkar muat dari kapal sampai ke tempat penumpukan atau sebaliknya dan membuat laporan secara periodik hasil kegiatan bongkar muat atau biasa disebut statemant of fact.. (b) Tallyman, yaitu pelaksana yang melakukan perhitungan pencatatan jumlah, merk dan kondisi setiap gerakan barang yang dibongkar atau dimuat dan ditulis di dalam daftar tally sheet bongkar atau tally sheet muat, untuk barang yang berupa general cargo dituliskan dalam dokumen tally sheet bongkar.. (c) Buruh/TKBM, yaitu personel yang bertugas untuk memasang sling pada barang yang akan diangkat dari kapal ke dermaga atau sebaliknya dan melepaskan sling pada barang yang telah dimuat atau dibongkar. (d) Operator Forklift, yaitu personel yang bertugas mengoperasikan forklif untuk mengangkut muatan dari dermaga ke gudang atau dari gudang ke dermaga (cargodoring). Ada dua orang operator forklift yang disiapkan oleh PBM dan satu operator forklift ditempatkan di dalam palka yang disiapkan guna untuk menyusun barang yang akan diangkat oleh crane ketika bongkar dan menata muatan general cargo didalam palka ketika sedang pemuatan, Setelah persiapan, selanjutnya kegiatan bongkar muat general cargo di Pelabuhan Merak Banten akan dilaksanakan. Berikut penyusun akan menjelaskan pelaksanaan kegiatan bongkar muat barang general cargo serta keselamatan apa saja yang harus dipakai untuk mendukung kelancaran pelaksanaan bongkar muat.

\section{Kedatangan Kapal}

Setelah kapal tiba kapal akan melakukan sandar di dermaga Pelabuhan Merak Banten untuk kegiatan bongkar muat general cargo. Semua peralatan dan personel yang dibutuhkan sudah siap dan berada di dermaga pelabuhan.

\section{Pelaksanaan Bongkar Muat Barang}

Setelah kapal bersandar serta semua persiapan untuk pelaksanaan kegiatan bongkar muat baik dan semua dokumen-dokumen, syarat-syarat yang diperlukan sudah terpenuhi sesuai dengan prosedur yang berlaku dan siap untuk melaksanakan kegiatan bongkar muat barulah kegiatan bongkar muat dengan proses sebagai berikut :

(1) Pelaksanaan Bongkar, yaitu sebelum pembongkaran barang dilaksanakan, foreman yang ditunjuk oleh perusahaan pelayaran dan foreman dari PBM naik ke atas kapal untuk konfirmasi dengan perwira kapal yaitu mualim 1 (chief officer) untuk memulai pelaksanaan pembongkaran barang muatan dengan menyesuaikan 
dari Stowage Plan dan packing list yang di bawa oleh foreman. Setelah sepakat barulah palka kapal dibuka dan foreman melihat dan memeriksa barang muatan di dalam palka, selanjutnya kegiatan pembongkaran dimulai. Sebelumnya pihak agent dan foreman melihat dan mencocokkan dengan inward manifest karena sebagai pedoman berapa banyak muatan dan jenis muatan yang dimuat di dalam palka kapal. Kegiatan pembongkaran muatan general cargo ini meliputi kegiatan pembongkaran langsung (truck lossing). (a). Pembongkaran Langsung (truck lossing), yaitu Pembongkaran barang dari kapal di mana barang tersebut diterima oleh penerima barang (consignee) tanpa melalui gudang lapangan penumpukan di pelabuhan dengan diangkut oleh kendaraan pengangkut seperti truck atau trailer yang berada langsung di sebelah lambung kapal pada saat pembongkaran. Kemudian langsung menuju ke gudang penerima barang atau gudang yang disewa penerima barang. Biasanya pembongkaran langsung di Pelabuhan Merak Banten mempunyai proses sebagai berikut:

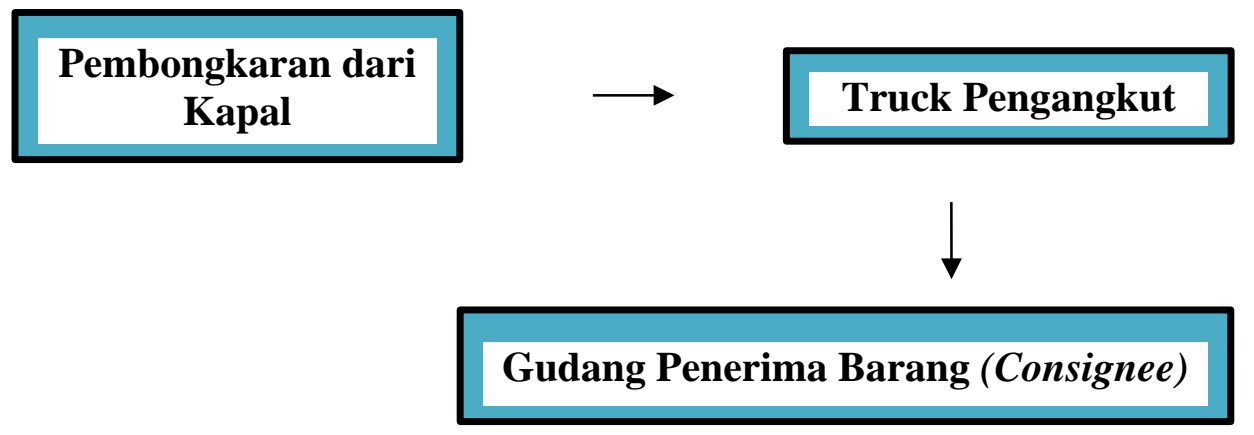

Gambar 4 : Skema Pembongkaran Secara Langsung (Truck Lossing\}

(b) Kendaraan pengangkut, yaitu seperti truck atau trailer langsung ditempatkan di posisi sebelah lambung kapal.

(2) Buruh/TKBM yang bertugas di dalam palka kapal memasang sling pada barang muatan di dalam palka kemudian barang muatan diangkat oleh crane dan diletakkan langsung ke dermaga lalu sling dilepaskan oleh buruh/TKBM yang bertugas di dermaga kemudian muatan dipindahkan menggunakan forklift ke atas truck. Begitupun seterusnya sampai truck terisi penuh dan barang sampai habis.

(3). Setelah truck pengangkut sudah penuh muatan sesuai dengan kapasitas angkutnya, truck langsung menuju ke gudang penerima barang atau gudang yang disewa penerima barang, kemudian truck selanjutnya yang masih kosong langsung ditempatkan diposisi sebelah lambung kapal untuk melakukan kegiatan yang sama dan begitupun seterusnya sampai barang muatan habis.

(4) Tallyman mencatat jumlah tiap barang yang diangkut oleh crane ke truck, jumlah barang yang diangkut pada tiap truck beserta plat nomor polisi pada truck tersebut serta total keseluruhan barang.

\section{Membuat Laporan Kerja}

Setelah pelaksanaan kegiatan bongkar dan muat selesai, maka chiefchecker membuat laporan sesuai dengan data-data dari realisasi pembongkaran dan pemuatan barang dalam bentuk time shett, statement of fact yang berisi keterangan 
atas semua waktu yang digunakan selama proses bongkar muat sampai selesai termasuk waktu istirahat kerja beserta keteranganya. Dalam dokumen ini juga terdapat keterangan mengenai hambatan yang dialami selama kegiatan berlangsung, alat-alat yang digunakan serta waktu kerjanya. Dokumen ini ditandatangani oleh agent, foreman dari PBM dan Mualim 1 (cheft officer) selaku perwira kapal yang bertanggungjawab atas muatan dan stabilitas kapal.

\section{Sebelum Kapal Berangkat}

Setelah pembongkaran selesai dan dokumen-dokumen telah di serahkan pihak kapal, pihak PBM PT.Berkah Tata Baruna segera membongkar alat-alat yang digunakan saat pelaksanaan bongkar muat.

\section{PENCEGAHAN RESIKO KERJA BONGKAR MUAT}

\section{Penerangan di Area Dermaga Pelabuhan}

Penerangan merupakan suatu aspek lingkungan fisik penting bagi keselamatan kerja. Penerangan yang tepat dan disesuaikan dengan pekerjaan berakibat produksi yang maksimal dan ketidak efisienan yang minimal, dan dengan begitu secara tidak langsung membantu mengurangi terjadinya kecelakaan. Dalam hubungan kelelahan sebagai sebab kecelakaan, penerangan yang baik merupakan usaha preventif. Pengalaman menunjukkan bahwa penerangan yang tidak memadai disertai tingkat kecelakaan yang tinggi.

\section{Pelatihan Kepada Tenaga Kerja Bongkar Muat}

Latihan keselamatan sangat penting mengingat banyaknya kecelakaan terjadi pada pekerja baru yang belum terbiasa dengan bekerja secara selamat. Sebabnya seperti ketidaktahuan tentang bahaya atau ketidaktahuan cara mencegahnya, sekalipun tahu tentang adanya suatu resiko bahaya tersebut. Ada pula tenaga kerja baru yang sebenarnya menaruh perhatian terhadap adanya bahaya, tetapi ia tidak mau disebut takut dan akhirnya menderita kecelakaan. Kejadian-kejadian demikian harus dihilangkan oleh latihan. Latihan untuk bekerja secara selamat tidak berbeda dari latihan untuk mencapapi efisiensi kerja yang tinggi. Segi keselamatan harus ditekankan pentingnya kepala tenaga kerja oleh pelatih, pimpinan kelompok atau instruktur.

\section{Pemakaian Warna, Peringatan dan Tanda-tanda Keselamatan}

Pemakaian warna, peringatan, dan tanda-tanda sangat penting bagi keselamatan kerja pada saat di pelabuhan. Pemakaian warna Aneka warna dipakai untuk maksud keselamatan, Dalam hubungan ini, terdapat penggunaan warna sebagai berikut (a) Warna menandakan daerah-daerah bahaya, peralatan penanggulangan kebakaran, perlengkapan pertolongan pertama terhadap kecelakaan, jalan ke luar, lalu lintas angkutan, dan sebagainya, (b) Secara khusus warna menunjukkan isi slinder gas dan pipa-pipanya. (c) Warna-warna yang tepat dapat memperbaiki berfungsinya indera pengelihatan seperti di tempat kerja, jalanjalan lalu lintas, dan sebagainya, (d) Warna-warna yang tepat bagi dinding, langitlangit, peralatan, dan lain-lain berefek psikologis yang baik. 


\section{Penggunaan Alat Safety Terhadap Pekerja}

Penggunaan alat safety kepada petugas bongkar muat yang berada di lapangan atau di pelabuhan sangatlah penting bagi keselamatan jiwa mereka saat bekerja. Penggunaan safety yang harus di pakai oleh para petugas yaitu helm safety, sarung tangan, sepatu safety, dan kata mata untuk melindungi mereka dari ancaman bahaya yang tidak di inginkan saat melakukan pekerjaan tersebut.

\section{Terjadinya Kecelakaan Kerja}

Penyebab kecelakaan kerja pada umumnya satu dengan yang lain saling berkaitan, apabila keselamatan dan kesehatan kerja tidak sepenuhnya dilaksanakan oleh karyawan. Untuk itu kemungkinan terjadinya kecelakaan kerja lebih besar dibandingkan dengan tempat lain, yang secara sungguh-sungguh melaksanakan aturan keselamatan dan kesehatan kerja. Kecelakaan-kecelakaan akibat kerja yang sering terjadi banyak disebabkan oleh factor manusia dan sedikit yang dipengaruhi oleh faktor alat. Adapun faktor manusia banyak dipengaruhi oleh: (a) Latar Belakang Pendidikan. Bahwa Latar belakang pendidikan banyak mempengaruhi tindakan seseorang dalam bekerja. Orang yang memiliki pendidikan yang lebih tinggi cenderung berpikir lebih panjang atau dalam memandang sesuatu pekerjaan akan melihat dari berbagai segi. (b) Faktor Psikologis, Faktor Psikologis juga sangat mempengaruhi terjadinya kecelakaan kerja. Psikologis seseorang sangat berpengaruh pada konsentrasi dalam melakukan suatu pekerjaan. Bila konsentrasi sudah terganggu maka akan mempengaruhi tindakan-tindakan yang akan dilakukan ketika bekerja. Sehingga kecelakaan kerja sangat mungkin terjadi. (c). Faktor Keterampilan, Keterampilan disini bisa diartikan pengalaman seseorang dalam melakukan suatu pekerjaan. Misalnya melakukan start atau stop pada sebuah peralatan, memakai alat-alat keselamatan, dan lain-lain. Pengalaman yang dibutuhkan ketika melakukan pekerjaan untuk menghindari kesalahan-kesalahan yang berakibat timbulnya kecelakaan kerja. (d) Faktor Fisik, Lemahnya kondisi fisik seseorang berpengaruh pada menurunnya tingkat konsentrasi dan motivasi dalam bekerja. Sedangkan kita tahu bahwa konsentrasi dan motivasi sangat dibutuhkan ketika bekerja. Bila sudah terganggu, kecelakaan sangat mungkin terjadi.

Terdapat beberapa penyebab kecelakaan kerja yaitu: (a) Muatan yang umumnya; menjadi sumber kecelakaan kerja dapat dibedakan menjadi dua kelompok besar, yakni barang berbahaya (hazardous cargoes) dan muatan biasa (common cargoes). Bahan hazardous goods jauh lebih berbahaya. Sedangkan muatan biasa dapat menjadi penyebab kecelakaan kerja mungkin disebabkan faktor manusia atau mekanisme kerja. (b) Manusia ; Faktor kesalahan manusia atau human error. Di berbagai konvensi internasional, kegiatan bongkar-muat barang di pelabuhan disebut dock work dan sumber daya manusia sebagai dock worker. Aktivitas bongkar-muat barang muatan kapal laut meliputi seluruh dan setiap bagian kegiatan bongkar atau muat setiap kapal definisi bongkar muat sebaiknya disusun dalam peraturan perundang-undangan nasional atau berupa pedoman pelaksanaan. TKBM yaitu sebagai dock worker yang melaksanakan dock work dapat merupakan penyebab terjadinya kecelakaan kerja, di antaranya apabila lalai mematuhi tata kerja barang berbahaya dan/atau barang biasa, tidak mengenal karakteristik barang yang dialayani atau tidak menggunakan alat-alat bantu yang

Majalah Ilmiah Bahari Jogja 39 | http://jurnal.stimaryo.ac.id/index.php/MIBJ/ 
disyaratkan. (c) Peralatan Bongkar Muat ; Peralatan bongkar-muat terdiri dari peralatan mekanis dan non mekanis. Setiap jenis alat tersebut harus terawat dengan baik dan diuji atau dikalibrasi sesuai menjalani perawatan atau perbaikan. Dalam hal pengawas operasi di lapangan meragukan keamanan peralatan peralatan bongkar-muat, maka peralatan tersebut tidak diizinkan untuk dipakai sampai dinyatakan layak untuk dioperasikan setelah menjalani perbaikan dan pengujian sesuai prosedur.

Kasus kecelakaan kerja sering kita jumpai di mana saja, yaitu kecelakaan kerja sering terjadi karena seringnya kelalaian tentang keselamatan diri sendiri dalam melakukan segala sesuatunya. Dalam kasus ini saya akan mencontohkan kecelakaan kerja saat terjadinya bongkar muat di pelabuhan Merak . Dalam kasus ini saya akan menceritakan kecelakaan kerja pada saat pembongkaran garam atau dry bulk di pelabuhan Merak. Saat di lakukannya pembongkaran tersebut pihak PBM PT. Berkah Tata Baruna lalai dalam mengecek alat bongkar muat yaitu sling pada crane yang kurangnya pemberian oli atau pelumas pada sling oleh sebab itu saat dilakukan pembongkaran tersebut sling yang kurang lancar saat crane dioperasikan membuat sling bermasalah dan mengenai dinding palka kapal.

Setelah terjadinya kecelakaan kerja seperti contoh di atas yaitu langkah pertama pihak operator crane dan TKBM akan melihat keruskan yang terjadi pada bagian yang terkena sling, serta memberhentikan aktivitas bongkar muat selama setengah jam sampai satu jam lamanya dan menunggu keputusan pihak PBM. Selanjutnya langkah kedua yaitu pihak Pelaksana lapangan PT. Atho Tama yang di wakilkan oleh chief checker akan menemui pihak master kapal untuk menanyakan kerusakan yang di akibatkan oleh pihak operator crane, Setelah menemui master pihak PBM akan berdiskusi dengan master kapal dan menanyakan permasalahan tersebut. Langkah ketiga pihak PBM akan mengganti biaya kerusakan pada palka kapal.

\section{SIMPULAN}

Sebelum pelaksanaan kegiatan bongkar muat general cargo diadakan persiapan alat perlengkapan dan SDM yang dibutuhkan yang harus dilaksanakan sebelum kapal datang dengan mengacu ketentuan perundang-undangan dan SOP perusahaan bongkar muat serta menjalankan sesuai kemampuan perusahaan agar tercapainya kelancaran dan terjaminnya keselamatan kerja bongkar muat.

Pentingnya Standar Keselamatan kerja bagi para pekerja dikarenakan untuk melindungi keselamataan saat melakukan sesuatu dengan menggunakan APD agar hal ini sebagai upaya terpenuhi ketentuan undang-undang tentang keselamatan kerja. Pencegahan risiko dan kecelakaan kerja yang terjadi dari skala kecil hingga besar pada dasarnya dapat dicegah melalui cara mengurangi kemungkinan terjadinya dan menanggulangi dengan cara melokalisasi akibatnya. Mencegah dan menanggulangi resiko dilakukan dengan memasang dan menyediakan APAR dan Instalasi Pemadam kebakaran, sesuai ketentuan Peraturan Menteri Tenaga Kerja Dan Transmigrasi RI Nomor 08/MEN/VII/2010: Tentang Alat Pelindung Diri (APD) . Kecelakaan kerja kerap kali terjadi pada suatu pekerjaan karena melanggar aturan keselamatan dan kesehatan dapat diakibatkan oleh latar belakang, psikologis,

Majalah Ilmiah Bahari Jogja 40 | http://jurnal.stimaryo.ac.id/index.php/MIBJ/ 
faktor keterampilan, faktor fisik, dan disebabkan oleh karakter muatan, faktor manusia, dan peralatan bongkar muat.

\section{DAFTAR PUSTAKA}

Agung, K. (2019). Fatika Risa Veronika., dan Didik Indriawan. Pengantar Manajemen Pelayaran Niaga.

Audi, A., Setiyantara, Y., Astriawati, N., \& Suganjar, S. (2021). Evaluasi Pelaksanaan Inert Gas System (Igs) Pada Kapal Tanker (Studi Kasus Di Kapal MT. Winson No. 5 Milik Perusahaan Winson Oil Singapore). JURNAL SAINS DAN TEKNOLOGI MARITIM, 21(2), 126-140.

Barasa Larsen and Sumali Bambang. (2019). Manajemen Logistik Maritim. Penerbit Djangkar.

Darmawi, H. (2014). Manajemen perbankan.

Hadi, S. (1978). Metode Reseach 1. Yogyakarta: Yayasan Penerbit Fakultas Psikologi Universitas Gajah Mada.

Iswanto, I. (2016). Bongkar Muat Barang Di Pelabuhan Intensitas Dan Aktivitas Suatu Tinjauan Empirik. Majalah Ilmiah Bahari Jogja, 14(23), 55-70.

Marzuki, P. M. (2007). Penelitian Hukum, Edisi Pertama, Cetakan ke-3. Kencana Prenada Media Group, Jakarta.

Narbuko, C., \& Achmadi, A. (n.d.). H, 2012. Metodologi Penelitian. Jakarta: PT Bumi Aksara.

PM Perhubungan RI Nomor 152 Tahun 2016: Tentang Perusahaan dan Pengusahaan Bongkar Muat dari dan ke kapal.

Peraturan Menteri Tenaga Kerja dan Transmigrasi RI Nomor 08/MEN/VII/2010 : Tentang Alat Pelindung Diri (APD).

Santosa, P. S., Astriawati, N., Pratama, W., Wibowo, W., \& Hartanto, B. (2021). Program Pelatihan Perlindungan Resiko Kebakaran Dengan Pengenalan Dan Penggunaan APAR. ABDIMAS UNWAHAS, 6(1).

Soekanto, S. (2007). Pengantar Penelitian Hukum [Introduction to Legal Research]. Jakarta: UI Press.

Suma'mur, P. K. (1981). Keselamatan kerja dan pencegahan kecelakaan. Gunung Agung.

Supartini, S., Dekanawati, V., Handojo, B., \& Juniarto, K. (2021). Implementasi Kesehatan dan Keselamatan Kerja (K3) bagi Pekerja Lapangan di Pelabuhan New Priok Container Terminal 1. Majalah Ilmiah Bahari Jogja, 19(2), 43-63.

Suyono, R. P. (2003). Shipping (pengapalan Internasional Ekspor-Impor Melalui Laut). Jakarta: BPM.

Tarwaka. (2008). Keselamatan Dan Kesehatan Kerja. Harapan Press.

Undang Undang No. 1 Tahun 1970, Tentang Keselamatan Kerja, (1970).

Wibowo, W., \& Astriawati, N. (2021). Sistem Pendingin Tertutup Pada Mesin Diesel Tipe Diesel MAK 8M32 Sebagai Penggerak Utama Kapal Motor LIT ENTERPRISE. Jurnal POLIMESIN, 19(1), 28-34.

Wibowo, W., Pratama, W., Astriawati, N., Santosa, P. S., \& Sahudiyono, S. (2021). Antisipasi Risiko Kebakaran Melalui Pelatihan Penggunaan Alat Pemadam Api Portable. SELAPARANG Jurnal Pengabdian Masyarakat Berkemajuan, 4(2), 357-361. 